\title{
Decolonizing mobile media: Mobile internet appropriation in a Guaraní community
}

Sarah Wagner and Mireia Fernández-Ardèvol, Open University of Catalonia, Barcelona

This is the accepted version of the following article.

Wagner, S. and Fernández-Ardèvol, M. (2020). Decolonizing mobile media: Mobile Internet appropriation in a Guaraní community. Mobile Media and Communication, 8(1), 83-103.

The published version can be found at:

https://journals.sagepub.com/doi/full/10.1177/2050157918822163 


\title{
Decolonizing mobile media: Mobile internet appropriation in a Guaraní community
}

\author{
Sarah Wagner ${ }^{1}$ and Mireia Fernández-Ardèvol ${ }^{2}$ \\ Internet Interdisciplinary Institute, Open University of Catalonia, Barcelona
}

\begin{abstract}
The internet has been a valuable resource for many indigenous groups as a vehicle for selfrepresentation. In this paper we describe how the installation of a Wi-Fi signal in a Guaraní community in Greater Buenos Aires—as part of the community leader's decolonizing media projects—generated issues within the community. While much indigenous media research concerns the politics of cultural representation, we consider the politics of everyday, intracommunity mobile communication practices. Firstly, our findings show how the choice of communication medium can become a political issue. An upsurge in mobile-mediated communication within the community contributed to the decline of face-to-face deliberations which were the mainstay for communal sharing arrangements and which held a central position in understandings of Guaraní culture. Secondly, our findings show how discrepancies between users' communication preferences and the readily available mobile media services can generate a use barrier by demotivating users from obtaining the skills needed to effectively appropriate or transform mobile media services. Familiarity with a few mainstream social media apps not only reinforced imaginaries of the internet as a non-indigenous space but also generated set ideas of what the internet supports in terms of communicative form—social networking-and content
\end{abstract}

\footnotetext{
${ }^{1}$ Sarah Wagner is a doctoral candidate at the Internet Interdisciplinary Institute, Barcelona. Using collaborative methods, her research explores the intersections of indigenous communicative ecologies and ICT service systems.

${ }^{2}$ Mireia Fernández-Ardèvol is a senior researcher at the Internet Interdisciplinary Institute, Barcelona. Mobile communication has been one of her main areas of study since 2003, with a combined sociological and economic focus. Her interests are set both in developed and in developing countries.
} 
type-mainstream media. In the end, the community leader's decolonizing projects aimed at using social media for community media dissemination were not only rejected by community members but also undermined by the dynamics of mobile media practices in the community. We argue that limited mobile technology skills combined with commercially oriented mobile media services can hinder creative and adaptable mobile media practices, and in turn, decolonizing mobile appropriations.

Keywords: mobile media; mobile communication; mobile internet; indigenous media; community communication; mobile technology appropriation; communicative ecology; digital inclusion; decolonization; cultural revitalization.

Leading up to the 2009 Audiovisual Communication Services Law's passage in Argentina, representatives of over 700 indigenous communities demanded the right to communication with identity. Representatives spoke up in public forums and across media channels to draw attention to inequalities in the management and production of media contents and communication technologies (see Wagner, 2015). As part of this movement, indigenous communicators published a manual in 2012 that set-out principles and values for indigenous communication, characterized as "the decolonization of the spoken word." The manual explains, "To decolonize our gestures, acts and the language with which we name the world... the challenge today is to build communication tools [emphasis added] in accordance with the individual strategies of 32 indigenous groups that speak 14 languages different from Spanish” (Baraldini, Cañicul, Cian, Juan, \& Melillán, 2012, p.32). ${ }^{1}$

Decolonization is an ongoing reversal of power structures, which marginalize, govern or speak for indigenous peoples, with actions of self-determination and self-representation (see Smith, 1999). In respect to media, much research in Latin America and elsewhere has analyzed 
the role of ICTs in supporting indigenous self-representation and advances in decolonizing agendas (Basanta, 2013; McCallum \& Waller, 2017; Magallanes-Blanco \& Ramos Rodríguez, 2016; Monasterios, 2003; Wilson, Carlson, \& Sciascia, 2017; Wilson \& Stewart, 2008). The many examples of indigenous groups obtaining ownership over television channels (Bell, 2008), radio stations (Magallanes-Blanco \& Ramos Rodríguez, 2016), mobile networks (Magallanes-Blanco \& Rodríguez-Medina, 2016; McMahon, 2011) and other digital technologies—such as social media servers (Budka, 2015; IRCA, 2016) and code writing languages (López-Vicent, Sánchez-Vera, \& Solano-Fernández, 2014)—go beyond interests in self-representation. These strategic acts of digital self-determination (McMahon, 2011) reveal the felt need to rebalance inequalities in the production and ownership of ICT services.

While there has been much interest in the empowering potential of mobile telephony particularly within developing contexts (see Donner, 2008; Fernández-Ardèvol, Galperin, \& Castells, 2011), concerns have amounted over mobile network neutrality. Platform providers and mobile carriers have a history of restricting communication services to protect proprietary interests (Wu, 2007; see also Goggin, 2011) and the architecture of mobile internet has been found to foster streamlined information-seeking patterns and reduced content development compared to personal computer internet use (Napoli \& Obar, 2014). Furthermore, online platforms and search engines are typically embedded with Western or East Asian cultural codes (see Srinivasan, 2012). Likewise, cultural revitalization research has found website and database architectures to devalue indigenous ways of knowing (Oppenneer, 2009; van Gelderen \& Guthadjaka, 2017). Meanwhile, indigenous communicators (see Wilson et al., 2017)—as many other social groups (Castells, 2012)—have advanced counterhegemonic movements using corporate-owned online sharing platforms such as Twitter and Facebook.

This article contributes to ongoing debates on the cultural politics of mobile telephony services in minority contexts by exploring the everyday practices of decolonizing mobile media. By 'mobile media' we mean the diverse modes of communication accessed, shared, produced or 
performed over mobile communication technologies (cf. Goggin, 2011, p.6). We present research conducted with a Guaraní community situated 30 kilometers from the Autonomous City of Buenos Aires, Argentina. The community leader's involvement in the communication with identity movement had spurred on interest in decolonizing communication services through community ownership and management. While a community radio station was planned, the projects in place at the time of research included a community Wi-Fi network and social media pages. The free Wi-Fi signal had incited an upsurge in mobile internet use. This initial phase of mobile internet appropriation is the focus of our research. We analyze the position of mobile internet practices within community members' negotiations of urban life, indigeneity and community belonging, and consider the interrelations of these practices with the leader's decolonizing agendas.

A common strategy for ICT-related cultural revitalization projects targeting indigenous communities in Argentina (see López-Vicent et al., 2014, pp. 6-7) and elsewhere in Latin America (Villacrés Roca, 2016, p. 112) is to provide digital platforms for documenting and sharing cultural contents. In the present research, sovereignty over communication platforms was more important to the political and cultural goals of the community's communication projects than the nature of distributed contents (i.e. 'indigenous' or 'Western').

\section{Theoretical considerations}

Along with much media anthropology research, we adopt a practice approach (see Birgit Brauchler \& Postill, 2010). Practice theory provides a conceptual lens onto the mutually constructive relation between the activities of agents and the sociocultural system in which they are situated (Ortner, 1984). Such an approach is pertinent to indigenous media research, which initially one-sidedly concerned the impacts of technologies on indigenous communities and not the ways indigenous peoples culturally construct and influence technologies (Salazar, 2007). Our interest is in the way routinized engagements with mobile media (see Moores, 2005) interrelate 
with sociocultural standpoints and technical affordances—or the material, relational or functional aspects that frame the possible uses and meanings of technologies (see Hutchby, 2001). To understand mobile media practices in this way we draw on two concepts commonly used in mobile communication literature: technology appropriation and communicative ecology.

\section{Technology appropriation}

Analyses of mobile appropriation consider the economic, social and technical implications of local use patterns (e.g. de Souza e Silva, Sutko, Salis, \& de Souza e Silva, 2011; Sey, 2011). Along with Bar et al. (2016) we maintain the appropriation process is political, "a contest for control over a technical system’s configuration” (p.618). Bar et al. outline three stages of technology innovation involving cycles of adoption, appropriation and repossession through which providers modify available services in response to users' innovations. In the appropriation phase, users negotiate providers' imagined uses for technologies, developing their own modes of communicating — personalizing services, altering hardware and software or even violating providers' restrictions (see also de Souza e Silva et al., 2011). In this way, users bring intended and unintended shifts (Ortner, 1984, p.157) to not only technical systems but also wider social, cultural and communicative contexts.

\section{Communicative ecology}

Communicative ecology refers to the 'whole' of communication/information activities, their interrelations and sociocultural framing (Slater, 2013). Applications of the term in mobile telephony research draw attention to the interdependency of mobile communication with other communication practices and socioeconomic circumstances (Miller \& Horst, 2006; Watson \& Duffield, 2016). Along these lines, Deleuze and Guattari's concept of the rhizome has been used in community media studies to theorize the interrelations of media and society as fluid and nonhierarchical (Carpentier, 2016). The rhizomatic approach offers an epistemic model for analyzing communicative ecologies in which researchers engage with the subject matter through multiple 
entry points and angles of analysis, enabling them to reconceptualize media practices as embedded in or subordinate to other social practices (Spitulnik, 2010). This not only moves researchers away from a media-centered approach but also enables portrayal of the transhegemonic nature of community media, which obtain community ends often through affiliations with state and commercial sectors (Carpentier, 2016).

\section{Methodology}

Smith's (1999) critical analysis of academia's colonizing role brought attention to the silencing, oppression and misrepresentation of indigenous knowledges through Western research frameworks. Despite ongoing debates on best practices for decolonizing methodologies, community-based collaboration is often considered an essential starting point (see Smith, 1999; Wingert \& White, 2017). The term 'community,' however, in social science research and in development practice is a contested issue, associated with slippage into presumptions of collective identity and local harmony (see Amit \& Rapport, 2002; Mohan \& Stokke, 2000). 'Community' among informants in this research referred to an extended family group that had obtained recognition as a Guaraní community by the federal institution for indigenous affairs. As a political category, it functioned like a "search space" in which individuals' divergent "wanderings" (Fortun, 2009, p. 178) in respect to their interests and identities were not only apparent but also recognized by informants as part of the community's make-up.

Planning for this collaborative research project began in September 2013 with the community leader, Julio, who was interested in bringing together community members' perspectives on ICTs to support the community's decolonizing communication projects. Individual members engaged in various stages of the research as per their own interests. Julio played a role in the overall research design while other informants became involved in decisions on the methods and analysis. The research was conducted in September 2014 and combined participant observation, group discussions and interviews. The first author resided with Julio's 
family for three weeks and spent most days joining his partner, Melina, on her daily circuits: taking children to school, chatting with others in the community center (a communal outdoor space situated between four households), shopping and preparing family meals. Detailed daily diaries were kept which paid particular attention to the routine uses of communication technologies.

Informal group discussions in the community center or in family homes were a regular occurrence during the research period. These discussions enabled collaborative reflection on the research process and themes arising in the analysis, such as the significance of face-to-face communication. At the end of the research period, the first author facilitated a workshop on social media as requested by Julio. This workshop was ensued by group discussion on community members' non-use of the cultural webpages managed by Julio.

Throughout the research period, interested community members partook in interviewsconducted in Spanish with an average length of 40 minutes-which explored their communicative resources and networks (Hearn, Tacchi, Foth, \& Lennie, 2009) as well as their perspectives on Guaraní culture, communication technologies and the social/political/cultural position of the community. Key characteristics of the 19 interview participants-including Julio and Melina—are listed in Table 1.

\section{[Insert Table 1]}

\section{Urban life: Invisibilization, discrimination and fragmentation}

Around the time of Spanish colonization, groups of Guaraní-speaking peoples were expanding southwestward into the Andean foothills (see Saignes, 2007) with presence in what is today northern Argentina since the early 1600s (Gordillo, 2011). The Guaraní heritage of the community in this research was traced through the maternal grandmother, born in Parapety, Bolivia and later settling in Salta province in northern Argentina. When the community formed in Glew in 1985-following a series of migratory paths from Salta province-there was no 
urban development and the living conditions were poor. As the city grew around them in the early 1990s, they spent seven years fighting for their rights to their settled land, finally attaining title to six parcels of land in 1998. At the time of research, the community was composed of 49 individuals with close family relation, based around nine siblings_-aged 26 to 47 —and their families.

From the community leader's perspective, the community remains politically and culturally invisible. Colonization and the formation of the Argentine nation operated to invisibilize indigenous peoples: the European identity of Argentina was propagated through educational materials and government documents, where indigenous peoples were characterized as marginal groups of the past or 'other' to the nation state (Gordillo \& Hirsch, 2003). While an estimated 31 percent of Argentina's indigenous population resides in Buenos Aires province (own calculation based on INDEC, 2010), the imaginary of indigeneity is strongly associated with the barren lands of the north and south; urban indigenous Argentineans are systematically negated—othered as 'negros', Bolivians or Paraguayans (Valverde et al., 2014).

The school was situated four blocks from the community center but there were no teachings about Guaraní culture or indigenous peoples other than as part of history lessons. Melina's sons aged six and ten had been bullied and called "girl" at school as, in her opinion, other students were unaware that Guaraní men have long hair. Daniela explained, "We need to let the others know something about us, about the Guaraní, so that there isn't discrimination. To be honest, they discriminated against me all the time at school." The Guaraní language was not spoken among community members resulting from years of discrimination. The maternal grandmother had been severely beaten for speaking Guaraní during her lifetime and had prohibited her children from learning the language. Middle-aged and older informants hoped to reintroduce Guaraní language and cultural knowledge back into the community through education projects, and a few members had visited northern Argentina and Bolivia to partake in Guaraní cultural events and political meetings. 
A central cultural concept among Guaraní political discourse in Argentina and Bolivia is ñande reko or 'our culture' (Hirsch, Huenuan, \& Soria, 2016; Wahren, 2012) which reflects the Guaraní understanding of well-being and is often associated with group unity or togetherness (see Wagner, 2018). Among community members, togetherness was not only a concept based on past traditions or promoted in Guaraní cultural movements but also a contemporary problem. Community members of all ages expressed concern that the community was fragmenting through the pressures of urban life. Luis explained, "Before there were more community activities... We had festivals and all of that. But everything stopped, and we have stopped. We are separated now... And as a community we are losing a lot."

Of the community's 13 households, six were located off community lands and four had members with regular employment in the Autonomous City of Buenos Aires, over an hour bus and train ride away. Maintaining cohesion had become difficult; families were individuated in their efforts to find employment, and experiences of discrimination impeded on efforts to unify members under a shared indigenous identity. Aurelio explained, “The city traps you. It consumes you. As we live here in a city, we are not free to have festivals or plant things. It changes us, the city... A lot of the time we need to work." Ramiro explained, "While you want to keep a certain type of life, the city makes you something else. As if it wants to globalize you... You want to maintain the culture, and the people, they discriminate against you."

To reunite the community and visibilize Guaraní culture, Julio was working on obtaining funding and permissions for communication media projects. In 2013, the community was the first in Greater Buenos Aires to obtain an indigenous radio license under the 2009 Audiovisual Communication Services Law. At the time of research, they had not yet inaugurated the FM radio station as further funding was needed for equipment. However, through an arrangement with a private internet service provider they erected a communications tower on community land in January 2014. The service provider covered the expense of the installation and uses the tower to provide internet for clients, while the community gained a free Wi-Fi signal and a tower from 
which they planned to broadcast FM radio. For many members residing near the community center, the Wi-Fi signal enabled the first-time engagement with mobile internet without paying per megabyte.

\section{Communicative architectures and community cohesion}

Mobile telephony was integrated in community members' communication habits, playing a prominent role in maintaining contact with strong ties throughout the day. Informants explained that mobile internet use in the community increased following the Wi-Fi launch as mobile data services were intermittent and expensive. Online instant messaging services enabled remote communication between households located off community lands — most of which had broadband installed at home - and those residing near the community center at no additional cost. This contributed to the waning prominence of face-to-face discussions in the community center-which was the site for group-based problem solving.

Formal community planning meetings were commonplace until Julio’s mother, the former leader, passed away a few years prior to the research period. Disagreements over leadership alongside financial hardships individuated families; fencing was erected on communal lands and priorities shifted from community projects to finding individual employment. Guaraní political practices in many areas of Argentina and Bolivia continue to be based on the traditional form of social organization— the assembly—where interchange and listening through group meetings play an important role (Castelnuovo Biraben, 2014; Lowrey, 2011; Wahren, 2012). That assemblies were no longer held in the community represented a symbolic disjuncture with their cultural heritage, something lamented by middle-aged and older informants. Yet, communal living practices were evident among those based in the community during the day. Women came together in the community center most afternoons, deliberating issues relating to youth, the school and family health, and at times, planning group income-earning activities. These informal discussions typically transpired over the group consumption of yerba mate, a common practice 
across Argentina that had particular significance for community members as a medium for unrushed, everyday exchanges carried out in a circular arrangement in the backyard (see also Hirsch et al., 2016). These relaxed, in-person communications provided opportunities for shared problem solving and supported ongoing communal arrangements, which continued to play an important role in community life: children stayed with other families for long periods, and food, kitchenware and mobile chargers regularly shifted between households.

Mobiles, however, were invariably considered personal devices; they facilitated contact among family members separated during the day and with families that had relocated closer to transport hubs. In this way, mobile communication compressed perceptions of community space, which had been expanded and dissociated through urban pressures. However, at the same time, mobile communication devalued communal places. The free Wi-Fi signal supported new forms of intracommunity communication among those home-based during the day which deterred from informal meetings in the community center. Partway through the research period, Melina obtained her first smartphone. Using Facebook and WhatsApp to message youth she learnt of community members' activities while at home. The opportunity for cost-free instant messaging meant some afternoons it was no longer necessary to walk four blocks to the community center. Some informants explicitly connected the prevalence of mobile communication to the dwindling cohesion of the community and the declining regularity of inperson communication between families. Laura, for example, explained, “If the phone didn't exist, then one would have to go to the other person's house and speak to that person, and now with these technologies we don't do that as much.”

At the time of research most community members could access internet services at home on their smartphone, feature phone or personal computer without cost difference between a wide selection of communication media. In what Madianou and Miller (2013) have called polymedia, the way community members shifted between communication media—such as instant messages, postings on homepages, voice calls or dropping by someone's house 
unannounced—not only had consequences for social relationships but also had political significance. For a few informants, the communication medium choice itself had become a political issue as intimate, in-person discussions held a central position in their understandings of Guaraní culture. More generally, community members' internet-based medium choices worked to reconstruct group norms on appropriate media in line with the forms of communication and media consumption that were already customary as well as preferences for more intimate modes of communication.

The way community members negotiated the remediation of media playback by mobile internet services exemplifies the role of group norms in guiding newfound medium choices. When Melina received her new smartphone, she began watching telenovelas on YouTube where she found newer episodes than those broadcasted on television networks. Melina appreciated the opportunity to independently choose media on her mobile yet resisted the opportunity to individualize the playback of these choices. She used the mobile's inbuilt speaker rather than the earphones, staying audibly present in the communal space. Community members of all ages contested the use of earphones. Informants lamented they could not play mobile radio as the FM receiver was placed in the earphones. The YouTube mobile application had become the most popular way to listen to music. Multiple sources of music typically emanated from mobiles in the community center. The non-use of earphones among community members meant that their individual playback choices were presented to a communal audience, and in this way reconfirmed ongoing group expectations for communal media consumption.

Analyses of ICT non-adoption can provide important insights on the relation between users and technologies (Brody, 2018; Neves, de Matos, Rente, \& Martins, 2015), and in indigenous contexts, have revealed interests in cultural safeguarding (e.g. Rodríguez \& El Gazi, 2007, p.457; van Gelderen \& Guthadjaka, 2017, pp.13-14). In the present research, instances of non-use that reflected a deliberate choice — rather than digital literacy levels or service costswere often intertwined with feelings of uneasiness when mobile communication was perceived 
to encroach on communal places or replace what were considered more mutually invested forms of communication. Non-use was often contextual and related to preferences for certain platforms or modes of communicating in a particular context or with a particular group of people.

Luciana, for example, used her mobile primarily to call her daughter residing over two kilometres away but never to communicate with those living close by. She resided adjacent to the community center on the largest, undivided area of community lands. Deficiencies in reading and writing meant she could not partake in messaging, but moreover, she was not interested in increasing her mobile use as family and friends frequently dropped by, often staying for hours, and she valued the leisurely discussions. Her resistance to mobile-mediated communication with neighbours was a way to safeguard in-person communication and to reinforce the prominence of the community center. Middle-aged and older informants explained that the intimacy of speaking in-person was an important Guaraní cultural practice; it echoed the communication style of assemblies and the Guaraní understanding of well-being as togetherness.

Julio previously owned a smartphone but had given it away as he preferred basic phones. He intentionally limited his mobile use to short updates and the coordination of in-person meetings as he did not want mobile communication to replace in-person communication particularly within the community. He explained,

\footnotetext{
We have traditional communication, which is the communication of meetings, assemblies, between people, when I want to talk to my child or my brother or my wife. It is important to have our communication, but if I need to contact someone in particular it is important that it is a voice call. Maybe the service cost communicating through Facebook or Twitter or WhatsApp is better... but I am not interested in using the social networks for [messaging people]... I am interested in direct communication with my siblings and my children and other colleagues.
}

For Julio, social networking services were inappropriate for interpersonal communication as they obscured what should be direct and in-person. Accessing social networks on the 
computer in the evenings, however, was important for his work as a Guaraní leader: "The social networks have helped us a lot as indigenous people ... My colleagues keep telling me that it is necessary, for the work that I am doing [as an indigenous leader].” Julio contained his use of Facebook and Twitter to the computer and in this way defined it as a work practice rather than a communicative practice.

Research on Facebook practices in indigenous contexts and elsewhere often account the popularity of Facebook's profile page (the 'Wall') for self-presentation and identity exploration (e.g. Manzi et al., 2018; Joinson, 2008; Lumby, 2010). In the present research, Facebook was most often used as a private messaging service. Other than Julio, adult informants were averse to online social networking and had fewer than 20 contacts in their Facebook network. Melina felt communicating with multiple people simultaneously online created division among family and friends. Alberto and Sergio purchased smartphones to access social networking services but, in the end, preferred not to engage in social networking. Alberto explained, "The thing is that here we share things only between us. We are very reserved." Alberto bought a smartphone after a friend passed away; he was late to learn of his friend's death as the message was communicated over Facebook. Sergio also felt pressured into buying a smartphone: "I went to buy this phone because in every direction people were saying to me, 'Do you have WhatsApp?'... 'Do you have Facebook?' And now I have it but don't put stuff up on it." He explained further,

\footnotetext{
I am a reserved person... my friends always say, 'Why are you on Facebook if you never comment on anything?' and this annoys them. But I am not a showy person... If I'm with a friend I might show them the photos [saved on his phone], but in this case I know that they want to see them.
}

For Sergio, an integral part of information-sharing and relationship-building is to know the other is invested, which for him requires a form of communication that is private and bidirectional.

Aversion to Facebook is neither unique to this context nor to certain age cohorts (Brody, 2018; Knowles \& Hanson, 2018; Neves et al., 2015). Rather than non-adoption—or not having a 
Facebook account—what was of interest in our research was the ways users negotiated and delimited their use of Facebook's platform to reproduce what they considered more intimate forms of communication. For most adults this meant delimiting Facebook use to private interpersonal messaging, and for Julio, limiting his access to social networking sites to the work sphere to safeguard "direct" communication with family and friends. As Neves et al. (2015) found amongst youth in Portugal, the choice to not participate in online social networking can reflect interests in offline identity performance. The delimitation of social networking practices and other communication media was a way to reconfirm one’s Guaraní identity by aligning oneself with more private and responsive forms of communication. Some informants, such as Luciana and Julio, explicitly connected their communication preferences to their interests in protecting Guaraní cultural practices, while others, such as Melina, Alberto and Sergio, explained their preferences in terms of group cohesion or communicative intimacy, both of which were considered important Guaraní values.

Facebook practices amongst youth played a different role. In addition to Facebook's private messaging service, youth users valued Facebook's profile page. With networks of often over 100 contacts built up through school ties, youth informants participated in trending content, commented on postings and reposted images and videos to their 'Wall'. While such social networking practices did not align with what many middle-aged and older informants considered Guaraní communication or characterized as the reserved nature of the community, these changes were welcomed. Youth members' online presence was seen by many middle aged and older informants as an important way for them to negotiate discrimination. Ramiro explained, "The others at school think that as indigenous peoples are in the [history] books, they no longer exist. So it is really important... that the youth can express and recount things from the community." Julio explained, "Always my objective with [providing communication tools] is that the youth can become involved in the social networks and transmit everything our culture stands for." 


\section{Media flows and cultural continuity}

Mass media around the world have contributed to the propagation of negative, historicized or exoticized stereotypes of indigeneity (see Leavitt, Covarrubias, Perez, \& Fryberg, 2015; McCallum \& Waller, 2017; Muñoz, 2010) and in Argentina, have been particularly criticized for invisibilizing indigenous peoples' contemporary rights and claims (Basanta, 2013). The main issue informants had with mass media was the omission of indigenous peoplesinformants lamented that drama series did not include indigenous characters and news programs did not cover indigenous peoples' activities and events. Discrimination towards indigenous peoples in Glew_as elsewhere in Argentina (INADI, 2014)—was commonplace in schools, hospitals and social security offices. Such systemic discrimination has been connected to not only the quality of mass media representations—or the propagation of negative stereotypes—but also the quantity of representations_-or the invisibility of indigenous peoples within portrayals of contemporary life (Leavitt et al., 2015). Some informants connected this invisibility in the media to the societal othering of indigenous peoples as non-Argentinean and the social- and selfdiscrimination experienced particularly by youth.

Youth attending school were challenged to self-identify as both indigenous and Argentinean. Mauricio and Federico no longer identified as Guaraní, a change which happened around the time they began secondary school. Mauricio explained, "Before when I went to primary school they said a lot of things to me, like about the colour of my skin, and for a period of time they didn't want to be near me." He now considered himself Argentinean and did not reveal his Guaraní heritage to school friends. Informants' concerns over cultural loss and the waning Guaraní identity of the community were often connected to youth. Aurelio explained, "I could go anywhere and I keep on being myself. I am not going to forget who I am. ... But this is for those of us of an older age. For the youth, it is a different story."

Representations of contemporary indigeneity were scarce in the internet media consumed by community members, which reinforced perceptions of the internet as a non- 
indigenous, international space. Personal computer internet was popular among youth for playing games found through Google's search engine; the resulting games were typically produced by American companies with graphics displaying English language matter. The children aged six, nine and ten in the homestay frequented YouTube on the household computer, opening popular links with images of cartoon characters or searching music groups and films they learned of from classmates. They directly associated the internet with English language games and American films. Mobile internet was particularly valued for music playing, which most often followed automated recommendations in the YouTube app based on searches for genres, songs or artists community members were familiar with through the radio, television, Facebook newsfeeds, school or workplace. Other than Julio, informants had not searched for Guaraní-related contents online. Yet there were many examples of informants engaging with and valuing offline digitized Guaraní media. Guaraní music CDs, language books and DVDs of cultural celebrations had entered the community through in-person exchanges with contacts from northern Argentina and Bolivia. Informants sometimes lamented the loss or breakage of such media while presuming similar contents were not available online.

Three mobile apps from Californian-based companies-WhatsApp, Facebook and YouTube-were the only apps being accessed among adult informants. These apps came preinstalled on feature phones and had become the norm for media playing and interpersonal mobile communication in the community. Most adults had never visited an app store or used a mobile internet browser as they lacked both the interest and the know-how. Daniela, for example, had learnt to use her Blackberry smartphone through manuals but skipped the chapters on internet browsing and apps due to lack of interest. Following the community Wi-Fi installation, she started using two preinstalled apps: YouTube to stream music and Facebook to message family and friends. She did not plan to explore other apps as she felt further engagements with mobile internet would be irrelevant to her interests. Aurelio valued ICTs particularly for playing Guaraní music and films which he had stored on CDs and DVDs—and 
some of which his daughter had copied to his smartphone-but he had not learnt how to access the internet or use apps as he considered it a waste of time. As discussed in the previous section, aversion to facets of mobile internet communication was common among adult informants particularly in respect to social networking. This aversion reflected political and cultural motivations as well as digital skills level.

Digital skills are an important part of what Selwyn (2004) has termed "meaningful access" to ICTs, which relates to users' abilities to control and manipulate features and contents. In the present research digital literacy levels were intertwined with perceptions on the cultural relevance of mobile media, as illustrated in Figure 1. Low digital literacy levels engendered streamlined mobile internet use patterns: adult informants not only were dependent on preinstalled apps or apps set-up by youth but also were limited in the way they used apps. This impeded on the appropriation process (Bar et al., 2016) as users lacked the ability to restructure services to suit their needs and wants. Mobile services were typically either used as intended and promoted by providers or rejected when the resulting communication practices were experienced negatively. Furthermore, streamlined uses of mobile internet reinforced reductionist imaginings of the internet in respect to the contents available and the communication forms supported. Most adult informants valued the few mobile internet services they did use-typically music video streaming and private online messaging — but they were not interested in augmenting their internet skills.

\section{[nsert Figure 1]}

While some informants had received formal training in computers, mobile skills were most often acquired through self-exploration with some assistance from youth. Youth had installed applications, uploaded media contents, set up user accounts and helped adults to understand social networking privacy settings. What was of interest was that most adults were not interested in seeking additional help from youth or in exploring further applications. Aurelio 
for example saw no use in the internet for himself ${ }^{2}$ while other adults such as Daniela felt they already used most of what the internet could offer them. The mainstream apps accessible to users with low-level digital skills generated an impression of the internet largely as a tool for locating mass media contents and partaking in social networking. Where gradations of access to ICT infrastructure, service affordability and digital literacy remain critical issues for digital inclusion (Salemink, Strijker, \& Bosworth, 2017; Selwyn, 2004), the present research draws attention to the way that discrepancies between users' communication preferences and the readily available ICT services can generate a use barrier by demotivating users from obtaining the skills needed to effectively appropriate or transform ICT services.

The incongruity of available mobile services with local needs and wants in some indigenous contexts has incited efforts to take over service provision (Magallanes-Blanco \& Rodríguez-Medina, 2016; McMahon, 2011). Julio’s communication media projects also aimed at local ownership. He explained, "Google has interests from another world, from other countries, so we need to create our own server, a server that would be of the Guaraní culture." In addition to developing their own search engine, Julio hoped one day they would manage a communitybased virtual mobile network. For the time being, he had launched three webpages: a blog site, a Facebook page and a Twitter account. The Guaraní term for 'culture' was included in the webpages and twitter account name and Julio regularly posted information about the community's projects as well as indigenous rights and movements. While Julio developed these webpages in early 2013 as a community project, other community members had not yet contributed contents. That adults were not interested in participating reflected their general discomfort with social networking and public forms of online communication. Meanwhile, the most active social networking users-youth—felt they had nothing to contribute about Guaraní culture.

Among youth, 'Guaraní culture' was associated with past traditions and practices which they knew little about and which, from their perspective, did not reflect the community's 
lifestyle. While Julio intended the pages as platforms for sharing present-day community activities, the explicit focus on Guaraní culture deterred youth interest. However, youth expressed interest in developing contents for the planned community radio project, particularly music programs featuring hip-hop or cumbia — the latter of which was favoured throughout the community. Informants envisioned the radio as a more open platform for community media dissemination (see also Rodríguez, Ferron, \& Shamas, 2014). While Julio’s webpages focused on 'Guaraní culture,' youth felt they could use the radio to exhibit the musical and cultural interests of the community today.

Informants of all ages supported the prospect of youth disseminating contemporary mainstream media content as community media. In fact, most informants did not envision Guaraní language and traditional cultural contents playing a principal role in the community's digital development. Julio had purposefully distanced the community from development initiatives that focused on the re-telling of traditional culture. Underpinning the social- and selfdiscrimination which both marginalized and fragmented the community was the social imaginary of indigenous peoples as unchanging and traditional, coupled with the presumption that one cannot be both indigenous and contemporary (see also de la Cadena \& Starn, 2007, p.9). Sergio explained:

I don't think [communication] technologies were produced with us in mind. They are made for other things. But, we use them. Before they used to say Indians (sic) communicated through smoke signals, but now we have cell phones in our pockets. There is always this kind of talk that Indians can't use technologies and still be Indians.

A common strategy in indigenous media productions has been the weaving together of past and contemporary cultural symbols to self-consciously transform, diversify and visibilize contemporary meanings of indigeneity (Ginsburg, 2008; Srinivasan, Enote, Becvar, \& Boast, 2009). In this research, informants spoke about the empowering potential of community media most often in relation to the fact of owning and managing services. While informants criticized 
mass media for invisibilizing indigenous peoples, Julio's projects did not intend to ameliorate this lack by disseminating characteristically indigenous contents. Rather, the prospect of redisseminating cumbia or hip-hop music from their own radio station was envisioned as a power reversal, shifting the origin of media and bringing value and noticeability to the community. We see here that the trans-hegemonic nature of community media (Carpentier, 2016) not only concerns alliances formed with non-communitarian actors but also content matter and can entail the redistribution of mainstream media content to realize community ends.

\section{Conclusion: Towards self-determination}

An important theme in much indigenous media research has been the political and cultural potential self-representation brings for organizations and individuals (Basanta, 2013; Landzelius, 2006; Monasterios, 2003; Virtanen, 2015; Wilson et al., 2017; Wilson \& Stewart, 2008). This article was concerned with everyday communication and media consumption practices and their intersections with the power structures embedded in mobile technology services. That is, our primary interest was the processes involved in decolonizing mobile services themselves. Our findings suggest that the effective use of mobile media for self-representation will involve an important self-determining process, in which sovereignty over the meanings and purposes of mobile media will be obtained.

We examined mobile media practices in an urban indigenous community in Argentina from the perspective of technology appropriation — as negotiations of technical systems — and communicative ecologies_as embedded in wider social/cultural/communicative contexts. Mobile communication was intertwined with the perceived arduousness of urban living, at once easing urban pressures by enabling ongoing contact with close ties and deepening urban influences by fostering communicative and media consumption practices which challenged efforts to maintain community cohesion. 
Some of the leader's intentions in sourcing a Wi-Fi signal—particularly his interest in fostering group cohesion through community media dissemination-were being undermined by community members' mobile media practices. First, an upsurge in online messaging reduced the frequency of in-person deliberations in the community center, which had been the mainstay for communal sharing arrangements. From Julio's perspective, it remained important that ICTmediated communication did not replace in-person communication within the community. Second, familiarity with a few mainstream social media apps had generated an impression of the internet as a non-indigenous, international or even American space. In effect, much of the internet-based media consumed in the community contributed to the invisibilization of contemporary indigeneity alongside other mass media channels like television. This invisibilization which permeated the school and neighborhood context challenged youth to identify as both indigenous and Argentinean and from Julio's perspective was a key issue in the fragmentation of the community's Guaraní identity.

That community members did not engage with Julio's communication projects-aimed at using mobile internet to disseminate community information— not only reflected the explicit focus of the webpages on Guaraní culture, which alienated youth members, but also the general unsuitability of mobile internet as a community media platform within the community context of mobile media practices. Mobile internet contents and applications accessed in the community were tied to interfaces, audience breadths and communication styles that did not appeal to all members. Local appropriations of mobile technologies transpired as community members rejected earphones or redefined Facebook as a private messaging service. Yet, feelings of constraint surrounding mobile use were prevalent particularly among adults. The multinational corporate grasp on the mobile media service arena combined with minimal digital skills meant that community members were almost exclusively using a few preinstalled applications, even when the resulting communicative practices were experienced negatively. 
Mobile network neutrality has gained significant attention and controversies have arisen over preinstalled and default services (European Commission, 2016) or other incentives such as zero-rating offers (Carrillo, 2016). While a new, convergent communication media law is underway in Argentina, previous policy narrowly defined audiovisual communication as television and radio broadcasting, eliminating internet and mobile media from debates on service monopolization and indigenous peoples' claims to communication with identity (Wagner, 2015). Locally-oriented mobile applications are scarce in Argentina and application developers tend to target international users as the architecture of dominant distribution platforms does not favour the local market (Wagner \& Fernández-Ardèvol, 2016). Network neutrality regulations in Argentina lack specificity (Becerra \& Mastrini, 2015) and in 2016 a zero-rating offer entered the mobile service arena, enabling credit-free access to the application WhatsApp ("Personal habilita el uso de Whatsapp," 2016).

The politically transformative potential of online media (Wilson et al., 2017) in our research context was inhibited in part by the cultural orientation of readily available mobile apps. Community members' “digital repertoire” (Donner, 2015)—their technical resources and accompanying digital skills—not only shaped mobile internet access in the community but also had implications for local cultural politics. Informants tended to have a set idea of what the internet supports in terms of communicative form—social networking —and content typemainstream and international media. This contributed to the digitally excluded position of the community as it demotivated community members from developing the digital skills needed to influence the social and cultural orientation of internet media. Mobile internet practices in effect were self-stagnating and intertwined with cultural concerns over shifting communicative practices and community fragmentation. The issues community members encountered in this initial phase of mobile internet appropriation is what spurred on the leader's long-term interests in taking control over mobile networks and media services. While these findings are contextspecific, they contribute to a growing body of research on the circumstances which incite 
indigenous ownership of mobile networks and services (Budka, 2015; Magallanes-Blanco \& Ramos Rodríguez, 2016; McMahon, 2011).

As mobile internet services are increasingly adopted in indigenous communities (Dyson, Grant \& Hendriks, 2016), indigenous media research requires perspectives beyond the politics of representation (see also McCallum \& Waller, 2017). Further engagements with political economy analyses (see also Rodríguez et al., 2014), informatics research on indigenous epistemologies (e.g. Srinivasan et al., 2009, van Gelderen \& Guthadjaka, 2017) and digital literacy research on indigenous ways of learning (e.g. Mills, Davis-Warra, Sewell, \& Anderson, 2016) will be important to grapple with the diversity of factors that influence mobile media practices.

\section{Notes}

1 All translations from Spanish are the authors' own.

2 This did not reflect negativity towards the internet in general; informants of all ages-including Aurelio-were keen for youth to gain internet skills. As found elsewhere among Guaraní (Wagner, 2018), the development of youth's digital skills was considered an important step in negotiating their marginalized position.

\section{References}

Amit, V. \& Rapport, N. (Eds.). (2002). The Trouble with Community (pp.12-70). London: Pluto Press.

Bar, F., Weber, M.S., \& Pisani, F. (2016). Mobile technology appropriation in a distant mirror: Baroquization, creolization, and cannibalism. New Media and Society, 18(4), 617-636.

Baraldini, V., Cañicul, M., Cian, C., Juan, C., \& Melillán, M. (Eds.). (2012). Comunicación con Identidad: Aportes para la Construcción del Modelo de Comunicación Indígena en Argentina. Buenos Aires: INAI.

Basanta, J.J. (2013). Comunicación y TIC en organizaciones indígenas de Argentina. TecCom 
Studies, 5(3), 31-37.

Becerra, M., \& Mastrini, G. (2015). New rules of the game in telecommunications in Argentina. Observacom. Retrieved from http://www.observacom.org/new-rules-of-the-game-intelecommunications-in-argentina/

Bell, W. (2008). A Remote Possibility: The Battle for Imparja Television. Alice Springs: IAD Press.

Brauchler, B., \& Postill, J. (Eds.). (2010). Theorising Media and Practice. New York: Berghahn Books.

Brody, N. (2018). Opting out of social media: Online communication attitudes mediate the relationship between personality factors and facebook non-use. Southern Communication Journal, 83(2), 75-88.

Budka, P. (2015). From marginalization to self-determined participation: Indigenous digital infrastructures and technology appropriation in northwestern Ontario's remote communities. Journal des Anthropologues, (142-143), 127-153.

Carpentier, N. (2016). Community media as rhizome : Expanding the research agenda. Journal of Alternative and Community Media, 1, 4-6.

Carrillo, A.J. (2016). Having your cake and eatinig it too? Zero-rating, net neutrality and international law. Stanford Technology Law Review, 19, 364-429.

Castells, M. (2012). Networks of Outrage and Hope: Social Movements in the Internet Age. Cambridge: Polity Press.

Castelnuovo Biraben, N. (2014). Dándole la palabra: Nuevas modalidades de liderazgo entre mujeres guaraníes del noroeste argentino. Universitas Humanistica, 79, 89-113.

de la Cadena, M., \& Starn, O. (Eds.). (2007). Indigenous Experience Today. Oxford: Berg. de Souza e Silva, A., Sutko, D., Salis, F., \& de Souza e Silva, C. (2011). Mobile phone appropriation in the favelas of Rio de Janeiro, Brazil. New Media and Society, 13(3), 411-426. 
Donner, J. (2008). Research approaches to mobile use in the developing world: A review of the literature. The Information Society, 24(3), 140-159.

Donner, J. (2015). After Access: Inclusion, Software and a More Mobile Internet. Cambridge: MIT Press.

Dyson, L.E., Grant, S., \& Hendriks, M (Eds.). (2016). Indigenous People and Mobile Technologies. New York: Routledge.

European Commission. (2016). Antitrust: Commission sends Statement of Objections to Google on Android operating system and applications. Retrieved from http://europa.eu/rapid/press-release_IP-15-4780_en.htm

Fernández-Ardèvol, M., Galperin, H., \& Castells, M., (Eds.). (2011). Comunicación Móvily Desarrollo Económico y Social en América Latina. Madrid: Fundación Telefónica.

Fortun, K. Figuring out ethnography. (2009). In J.D. Faubian \& G.E. Marcus (Eds.), Fieldwork is not What it Used to Be (pp.167-183). New York: Cornell University Press.

Ginsburg, F. (2008). Rethinking the digital age. In P. Wilson \& M. Stewart (Eds.), Global Indigenous Media (pp.127-144). Atlanta: Duke University Press.

Goggin, G. (2011). Global Mobile Media. New York: Routledge.

Gordillo, G. (2011). Longing for elsewhere: Guaraní reterritorializations. Comparative Studies in Society and History, 53(4), 855-881.

Gordillo, G., \& Hirsch, S. (2003). Indigenous struggles and contested identities in Argentina: Histories of invisibilization and reemergence. Journal of Latin American Anthropology, 8(3), 430.

Hearn, G., Tacchi, J., Foth, M., \& Lennie, J. (2009). Action Research and New Media. Cresskillm NJ: Hampton Press.

Hirsch, S., Huenuan, C., \& Soria, M. (2016). Guaranies, Chanés y Tapietes del Norte Argentino: Construyendo el Ñande Reko para el Futuro. Buenos Aires: Ministerio de Educación y Deportes. 
Hutchby, I. (2001). Technologies, texts and affordances. Sociology, 35(2), 441-456.

INADI. (2014). Mapa Nacional de la Discriminación, Segunda Edición. Buenos Aires: Instituto Nacional contra la Discriminación la Xenofobia y el Racismo.

INDEC. (2010). Censo 2010. Retrieved from http://www.censo2010.indec.gov.ar/index.asp

IRCA. (2016). Indigitube. Retrieved from http://indigitube.com.au/

Joinson, A.N. (2008). 'Looking at', 'looking up' or 'keeping up with' people? Motives and uses of Facebook. CHI 2008 Proceedings, 1027-1036.

Knowles, B., \& Hanson, V.L. (2018). The wisdom of older technology (non)users. Communications of the ACM, 61(3), 72-77.

Landzelius, K. (Ed.). (2006). Native on the Net: Indigenous and Diasporic Peoples in the Virtual Age. London: Routledge.

Leavitt, P.A., Covarrubias, R., Perez, Y.A., \& Fryberg, S.A. (2015). “Frozen in time:” The impact of native American media representations on identity and self-understanding. Journal of Social Issues, 71(1), 39-53.

López-Vicent, P., Sánchez-Vera, M., \& Solano-Fernández, I. (2014). Las TIC para el desarrollo de la identidad digital y cultural de pueblos originarios. Papeles de Trabajo sobre Cultura, Educación y Desarrollo Humano, 10(1), 10-18.

Lowrey, K. (2011). Ethics, politics, and host space: A comparative case study from the South American Chaco. Comparative Studies in Society and History, 53(04), 882-913.

Lumby, B. (2010). Cyber-indigeneity: Urban indigenous identity on Facebook. Australian Journal of Indigenous Education, 39, 68-75.

Madianou, M., \& Miller, D. (2013). Polymedia: Towards a new theory of digital media in interpersonal communication. International Journal of Cultural Studies, 16(2), 169-187. 
Magallanes-Blanco, C. and Rodriguez-Medina, L. (2016). Give me a mobile and I will raise a community. In L. Robinson, J. Spence and H. S. Dunn (Eds.), Communication and Information Technologies Annual, vol. 12. Bingley: Emerald, pp.315-343.

Magallanes-Blanco, C., \& Ramos Rodríguez, J.M. (Eds.). (2016). Miradas propias: Pueblos Indígenas, Comunicación y Medios en la Sociedad Global. Quito: CIESPAL.

McCallum, K., \& Waller, L. (2017). Indigenous media studies in Australia: Traditions, theories and contemporary practices. In J. Budarick \& G. Hann (Eds.), Minorities and Media: Producers, Industries and Audiences (pp.105-124). London: Palgrave Macmillan.

McMahon, R. (2011). The institutional development of indigenous broadband infrastructure in Canada and the United States: Two paths to "digital self-determination." Canadian Journal of Communication, 36, 115-140.

Manzi, C., Coen, S., Regalia, C., Yévenes, A.M, Giuliani, C, Vignoles, V.L. (2018). Being in the Social: A cross-cultural and cross-generational study on identity processes related to Facebook use. Computers in Human Behavior, 80, 81-87.

Miller, D., \& Horst, H. (2006). The Cell Phone: An Anthropology of Communication. Oxford: Berg.

Mills, K.A., Davis-Warra, J., Sewell, M., \& Anderson, M. (2016). Indigenous ways with literacies: transgenerational, multimodal, placed, and collective. Language and Education, 30(1), 1-21.

Mohan, G., \& Stokke, K. (2000). Participatory development and empowerment: The dangers of localism. Third World Quarterly, 21(2), 247-268.

Monasterios, G. (2003). Usos de internet por Organizaciones Indígenas de Abya Yala: Para una alternativa en políticas comunicacionales. Revista Comunicación, 122, 60-69.

Muñoz, C.V. (2010). Emergencia indígena mass mediática: Acción colectiva de autorepresentación social y legitimación. Comunicación y Medios, 21, 90-105.

Moores, S. (2005). Media/Theory: Tbinking about Media and Communications. Milton Park: Routledge. 
Napoli, P.M., \& Obar, J.A. (2014). The emerging mobile internet underclass: A critique of mobile internet access. The Information Society, 30(5), 323-334.

Neves, B.B., de Matos, J.M., Rente, R., \& Martins, S.L. (2015). The “non-aligned”: Young people's narratives of rejection of social networking sites. Young, 23(2), 116-135.

Oppenneer, M. (2009). Using ICTs for indigenous cultural preservation: challenges and strategies. Retrieved from http://www.ethnosproject.org/using-icts-for-indigenouscultural-preservation/

Ortner, S.B. (1984). Theory in anthropology since the sixties. Comparative Studies in Society and History, 26(1), 126-166.

Personal habilita el uso de Whatsapp sin límites para clientes prepagos (2016, October 31), La Nación. Retrieved from http://www.lanacion.com.ar/1952077-personal-habilita-el-uso-dewhatsapp-sin-limites-para-clientes-prepagos

Rodríguez, C., \& El Gazi, J. (2007). The poetics of indigenous radio in Colombia. Media, Culture and Society, 29(3), 449-468.

Rodríguez, C., Ferron, B., \& Shamas, K. (2014). Four challenges in the field of alternative, radical and citizens' media research. Media, Culture and Society, 36(2), 150-166.

Saignes, T. (2007). Historia del Pueblo Chiriguano. Lima: IFEA.

Salazar, J.F. (2007). Indigenous peoples and the cultural construction of Information and Communication Technology (ICT) in Latin America. In L.E. Dyson, M. Hendriks, \& S. Grant (Eds.), Information Technology and Indigenous People (pp.1966-1975). Hershey: Information Science Publishing.

Salemink, K., Strijker, D., \& Bosworth, G. (2017). Rural development in the digital age: A systematic literature review on unequal ICT availability, adoption, and use in rural areas. Journal of Rural Studies, 54, 360-371. 
Selwyn, N. (2004). Reconsidering political and popular understandings of the digital divide. New Media and Society, 6(3), 341-362.

Sey, A. (2011). "We use it different, different": Making sense of trends in mobile phone use in Ghana. New Media and Society, 13(3), 375-390.

Slater, D. (2013). New Media, Development and Globalization. Cambridge: Polity Press.

Smith, L.T. (1999). Decolonirzing Methodologies: Research and Indigenous Peoples. London: Zed Books.

Spitulnik, D. (2010). Thick context, deep epistemology: A meditation on wide-angle lenses on media, knowledge production and the concept of culture. In B. Brauchler \& J. Postill (Eds.), Theorising Media and Practice (pp. 105-126). New York: Berghahn Books.

Srinivasan, R. (2012). Re-thinking the cultural codes of new media: The question concerning ontology. New Media and Society, 15(2), 203-223.

Srinivasan, R., Enote, J., Becvar, K.M., \& Boast, R. (2009). Critical and reflective uses of new media technologies in tribal museums. Museum Management and Curatorship, 24(2), 161-181.

Valverde, S., Engelman, J., Aurand, M., Castellano, V., Landabouru, L., Pérez, A., ... Crosa, Z. (2014). Los Pueblos Indígenas en las ciudades: Una realidad desconocida. Proyecto Ubanex. Universidad de Buenos Aires.

van Gelderen, B., \& Guthadjaka, K. (2017). The Warramiri website: applying an alternative Yolyu epistemology to digital development. Research and Practice in Technology Enhanced Learning, 12(14), 1-19.

Villacrés Roca, J.R. (2016). Incidencia del uso de las TIC en los hábitos y costumbres de jóvenes de cultra kichwa en Ecuador. Asian Journal of Latin American Studies, 29(1), 109-131.

Virtanen, P.K. (2015). Indigenous social media practices in Southwestern Amazonia. AlterNative, 11(4), 350-362.

Wagner, S. (2015). The politics of mobile media inclusion in Argentina. In C. Wamala-Larsson, 
C. Scharff, \& J. Hellström (Eds.), Mobile Participation: Action, Interaction and Practices (pp. 37-

45). Newcastle, UK: Cambridge Scholars Publishing.

Wagner, S. (2018). Cultural revitalization and the ontology of communicative spaces: 'Mobile coordinating' among Guaraní. International Journal of Cultural Studies. Advance online publication. doi:10.1177/1367877918793429.

Wagner, S. \& Fernández-Ardèvol, M. (2016). Local content production and the political economy of the mobile app industries in Argentina and Bolivia. New Media and Society, 18(8), 1768-1786.

Wahren, J. (2012). La reconstrucción organizativa del pueblo guaraní en Bolivia y sus acciones colectivas por el territorio. Revista Sociedad y Equidad, 4, 44-63.

Watson, A.H.A., \& Duffield, L.R. (2016). From garamut to mobile phone: Communication change in rural Papua New Guinea. Mobile Media and Communication, 4(2), 270-287.

Wilson, A., Carlson, B., \& Sciascia, A. (2017). Reterritorialising social media: Indigenous people rise up. Australasian Journal of Information Systems, 21, 1-4.

Wilson, P., \& Stewart, M. (Eds.). (2008). Global Indigenous Media: Cultures, Poetics, and Politics. Durham: Duke University Press.

Wingert, S., \& White, J. (2017). Introduction to the special issue: Reconciling research: Perspectives on research involving indigenous peoples. The International Indigenous Policy Journal, 8(2), 1-11.

Wu, T. (2007). Wireless net neutrality: Cellular carterfone and consumer choice in mobile broadband (New America Foundation Working Paper No. 17). Retrieved from https://www.newamerica.org/oti/policy-papers/wireless-net-neutrality-cellular-carterfoneand-consumer-choice-in-mobile-broadband/ 
Table 1

Information about interview respondents

\begin{tabular}{|c|c|c|c|c|c|c|c|}
\hline Indicator $^{a}$ & Age & Sex & Employment & $\begin{array}{l}\text { Mobile } \\
\text { phone }^{b}\end{array}$ & Uses Internet & $\begin{array}{l}\text { Access to } \\
\text { computer }\end{array}$ & $\begin{array}{l}\text { Uses Social } \\
\text { Networking } \\
\text { Sites }\end{array}$ \\
\hline Camila & 14 & $\mathrm{~F}$ & Student & Smart & Community Wi-Fi & In house & $\begin{array}{l}\text { Facebook, } \\
\text { Twitter }\end{array}$ \\
\hline Roque & 14 & M & Student & Smart & $\begin{array}{l}\text { Broadband in } \\
\text { house }\end{array}$ & In house & Facebook \\
\hline Federico & 15 & $M$ & Student & Feature & Community Wi-Fi & No & Facebook \\
\hline Mauricio & 15 & M & Student & Smart & Community Wi Fi & $\begin{array}{l}\text { Father's } \\
\text { house }\end{array}$ & Facebook \\
\hline Laura & 16 & $\mathrm{~F}$ & Student & Smart & $\begin{array}{l}\text { Broadband in } \\
\text { house }\end{array}$ & In house & Facebook \\
\hline Luis & 17 & $\mathrm{M}$ & Unemployed & None & $\begin{array}{l}\text { Broadband in } \\
\text { house }\end{array}$ & In house & No \\
\hline Daniela & 22 & $\mathrm{~F}$ & $\begin{array}{l}\text { Primary } \\
\text { caretaker }\end{array}$ & Smart & Community Wi-Fi & No & Facebook \\
\hline Juan & 24 & $M$ & Cook & Smart & Community Wi-Fi & No & Facebook \\
\hline Ramiro & 26 & M & $\begin{array}{l}\text { Unemployed/ } \\
\text { studying }\end{array}$ & Basic & $\begin{array}{l}\text { Sister's } \\
\text { house/Internet } \\
\text { center }\end{array}$ & $\begin{array}{l}\text { Sister's } \\
\text { house }\end{array}$ & Facebook \\
\hline Valeria & 27 & $\mathrm{~F}$ & $\begin{array}{l}\text { Primary } \\
\text { caretaker }\end{array}$ & Smart & $\begin{array}{l}\text { Mobile } \\
\text { network/Community } \\
\text { Wi-Fi }\end{array}$ & No & Facebook \\
\hline Alberto & 28 & $M$ & Cashier & Smart & Mobile network & In house & Facebook \\
\hline Melina & 29 & $\mathrm{~F}$ & $\begin{array}{l}\text { Primary } \\
\text { caretaker }\end{array}$ & Smart & Community Wi-Fi & In house & Facebook \\
\hline Sergio & 33 & M & $\begin{array}{l}\text { Administration/ } \\
\text { studying }\end{array}$ & Feature & Mobile network & In house & Facebook \\
\hline Julio & 44 & M & $\begin{array}{l}\text { Construction } \\
\text { (intermittent) }\end{array}$ & Basic & Community Wi-Fi & In house & $\begin{array}{l}\text { Facebook, } \\
\text { Twitter }\end{array}$ \\
\hline Luciana & 47 & $\mathrm{~F}$ & $\begin{array}{l}\text { Primary } \\
\text { caretaker }\end{array}$ & Feature & No & No & No \\
\hline Fernando & 52 & M & Maintenance & Smart & Community Wi-Fi & No & Facebook \\
\hline Simona & 58 & $\mathrm{~F}$ & $\begin{array}{l}\text { Primary } \\
\text { caretaker }\end{array}$ & Feature & No & In house & No \\
\hline Clemente & 76 & M & $\begin{array}{l}\text { Retirement } \\
\text { pension }\end{array}$ & None & No & No & No \\
\hline Aurelio & 77 & M & $\begin{array}{l}\text { Regional } \\
\text { Guaraní } \\
\text { representative }\end{array}$ & Smart & No & In house & No \\
\hline
\end{tabular}

a Names have been changed to preserve anonymity.

b Mobile phones are categorized as following: 'Basic' phones are bar or flip phones with voice and texting service; 'Feature' phones additionally have touchscreens and Internet access; and, 'Smart' phones have advanced operating systems (Android or Blackberry in this research) and computerenabled features.

Source: own elaboration. 
Figure 1

Relation between digital skills and the perceived relevance of mobile media

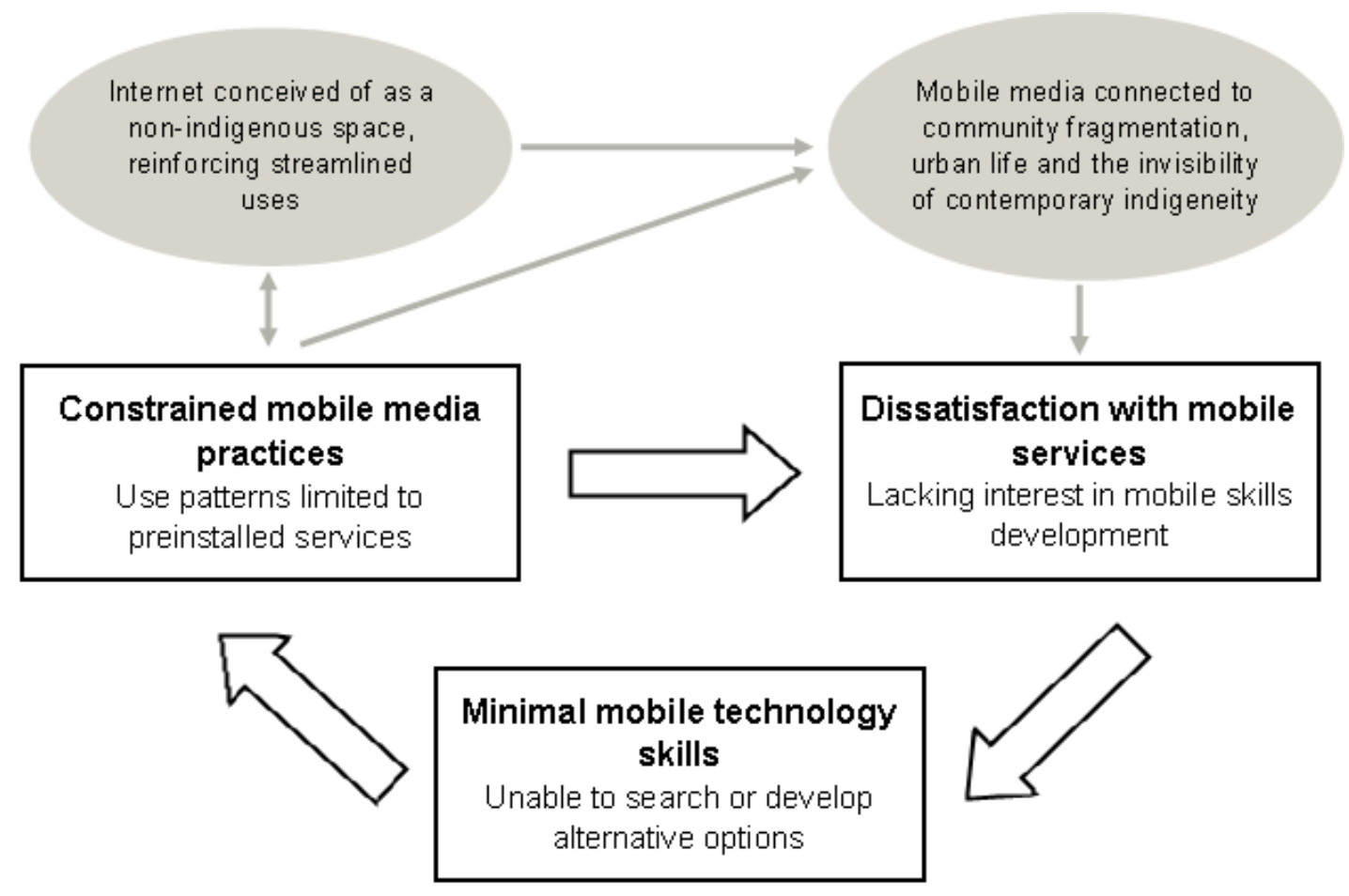

The lower section-in black-illustrates the general relation between digital skills level, use patterns and service dissatisfaction while the upper section-in grey-outlines contextual factors in the present research which reinforced users' streamlined mobile internet practices and dissatisfaction with mobile services.

Source: own elaboration. 